\title{
Nýgengi, orsakir og meðferð við bráðu rofi á ristli á Íslandi 1998-2007
}

\author{
Kristín Jónsdóttir læknir ${ }^{1}$, Elsa B. Valsdóttir læknir ${ }^{1,2}$, Shreekrishna Datye læknir ${ }^{3}$, Fritz Berndsen læknir \\ Páll Helgi Möller læknir ${ }^{1,2}$
}

\section{Á G R I P}

Inngangur: Rof á ristli er alvarlegt sjúkdómsástand með háa dánartíðni. Áður fyrr var meðferðin fyrst og fremst skurðaðgerð en á undanförnum árum hafa rannsóknir sýnt sambærilegan árangur með stuðningsmeðferð. Tilgangur pessarar rannsóknar var að skoða nýgengi, orsakir, meðferð og afdrif sjúklinga með brátt rof á ristli á Íslandi á tímabilinu 1998-2007. Efniviður og aðferðir: Gerð var afturskyggn leit í sjúkraskrám Landspítala, Sjúkrahússins á Akureyri og Heilbrigðisstofnunar Vesturlands á Akranesi að líklegum greiningarkóðum miðað við greiningarkerfi Alpjóðaheilbrigðisstofnunarinnar. Safnað var gögnum um kyn, aldur, greiningarár, orsakir, greiningu, meðferð og afdrif einstaklinga með brátt rof á ristli. Niðurstöður: 225 sjúklingar uppfylltu skilyrði rannsóknarinnar, 131 kona (58\%) og 94 karlar (42\%). Miðgildi aldurs var 70 ár (bil 30-95 ár). Algeng- ustu ástæður rofs voru sarpabólga (67\%), áverki við ristilspeglun (12\%) og fylgikvillar aðgerða. Á fyrri 5 árum rannsóknartímabilsins fengu 27\% sjúklinganna meðferð án aðgerðar en $71 \%$ fór í aðgerð. Á seinni 5 árunum var hlutfallið $45 \%$ og $54 \%$. Um $24 \%$ sjúklinganna fengu varanlegt stóma. Tæpur helmingur sjúklinga, eða 101 (46\%), fékk 140 fylgikvilla og var skurðsárasýking par algengust. Prjátíu daga dánartíoni var 11\% en eins árs dánartí̋ni $20 \%$.

Ályktun: Sarpabólga var algengasta orsök rofs á ristli á Íslandi á rannsóknartímabilinu. Á sama tímabili jókst notkun stuðningsmeðferðar á meðan skurðaðgerðum fækkaði. Hlutfall peirra sjúklinga sem fengu stóma og fóru síðar í aðgerð par sem gerð var endurtenging er hátt hérlendis og fyllilega sambærilegt pví sem lýst er í erlendum rannsóknum.

\section{Inngangur}

Rof á ristli er sjúkdómsástand sem margir sjúkdómar geta valdið. Раð er vel pekkt að sarpabólga (diverticulitis) valdi rofi á ristli en aðrar pekktar orsakir eru krabbamein, blóðpurrð og bólgusjúkdómar í ristli. ${ }^{1,2}$ Ristilspeglun, hvort sem hún er til greiningar eða meðferðar, er pekktur áhættupáttur rofs. ${ }^{3-5}$ Aðrar orsakir eru utanaðkomandi áverkar eins og slys og fylgikvillar aðgerða. ${ }^{2}$ Rofi á ristli hefur einnig verið lýst eftir tölvusneiðmyndatöku af ristli. ${ }^{6}$

Meðferð við rofi á ristli fer eftir orsökum pess og ástandi sjúklings. Framan af fóru flestir sjúklingar sem greindust með rof á ristli í skurðaðgerð., ${ }^{3,4}$ Hefðbundin meðferð við rofi vegna sarpabólgu hefur lengst af verið brottnám á peim hluta ristils par sem rofið er, ásamt ristilstóma (colostomy), eða svokölluð Hartmannsaðgerð. Síðar, pegar sjúklingar hafa náð sér, er mögulegt að framkvæma aðgerð par sem gerð er endurtenging eða samtenging (anastomosis) milli ristilenda. Samkvæmt erlendum rannsóknum er hlutfall peirra sjúklinga sem ekki fara í endurtengingu hátt, eða $45-54 \%{ }^{8,9,10}$

Á undanförnum árum hefur meðferð við rofi á ristli verið að breytast. Hlutfall peirra sjúklinga sem fá stuðningsmeðferð hefur farið hækkandi en hlutfall peirra sem fara beint í aðgerð hefur farið lækkandi. Stuðningsmeðferð hjá sjúklingum með staðbundið rof á ristli felur í sér sýklalyfjagjöf og eftir pörfum ástungu og

'Skurðlækningadeild Landspítala, ${ }^{2}$ læknadeild Háskóla Íslands, ${ }^{3}$ Sjúkrahúsinu á Akureyri, ${ }^{4}$ Heilbrigðisstofnun Vesturlands.

Fyrirspurnum svarar Elsa Björk Valsdóttir elsava@landspitali.is

https://doi.org/10.17992//bl.2017.02.121

Greinin barst 18. febrúar 2016, sampykkt til birtingar 2. janúar 2017. ísetningu kera í graftarkýli gegnum húð, sem settir eru með hjálp ómskoðunar eða tölvusneiðmyndar. ${ }^{12,13}$

Við ákveðin skilyrði hefur verið sýnt fram á jafngóðan árangur af brottnámi á hluta af ristli (colon resection) og samtengingu milli ristilenda í sömu aðgerð og við Hartmanns-aðgerð.,11 Pá eru vaxandi vísbendingar um að hjá sjúklingum með rof á ristli og dreifða lífhimnubólgu sé ef til vill hægt að ná sambærilegum árangri með skolun á kviðarholi og ísetningu kera með kviðsjárspeglun og við opna aðgerð. ${ }^{14,15}$ Ef pörf krefur er ristillinn fjarlægður síðar í valaðgerð eftir að bólga og sýking hefur hjaðnað. ${ }^{12-15}$

Dánartíðni vegna rofs á ristli er breytileg eftir rannsóknum, eða á bilinu 0-39\%, allt eftir ástæðum pess og alvarleika. ${ }^{2,3,7,11,16}$ Flestar rannsóknir um rof á ristli fjalla um afmarkaðan hluta sjúklinga, ýmist pá sem hafa sömu undirliggjandi orsök eða hafa fengið sömu meðferð. ${ }^{3,4,6,15,17}$ Höfundum er ekki kunnugt um að allir sjúklingar með rof á ristli, óháð orsökum og meðferð, hafi áður verið skoðaðir saman og pað á landsvísu.

Tilgangur pessarar rannsóknar var að skoða nýgengi, orsakir og meðferð rofs á ristli á Íslandi á tímabilinu 1998 til 2007 og kanna sérstaklega hvort breyting hafi orðið á meðferð á rannsóknartímabilinu. Einnig var árangur meðferðar metinn með tilliti til fylgikvilla og pörf á endurteknum inngripum. Pá var litið á hversu margir sjúklingar fengu varanlegt stóma.

\section{Efniviður og aðferðir}

Rannsóknin var afturskyggn og náði til sjúklinga priggja stærstu sjúkrahúsa landsins, Landspítala, Sjúkrahússins á Akureyri og Heilbrigðisstofnunar Vesturlands á Akranesi, á tímabilinu 1. janúar 1998 til 31. desember 2007. Gengið var út frá pví að sjúklingar með rof á ristli væru ekki meðhöndlaðir á öðrum sjúkrahúsum. 


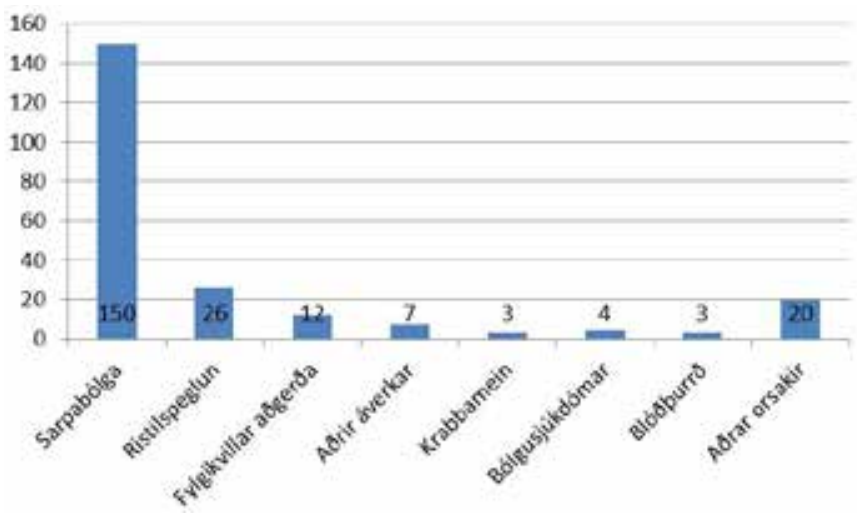

Mynd 1. Ástæður rofs á ristli (n=225).

Rof á ristli var skilgreint sem staðbundið graftarkýli við ristil, graftarkýli í kviðarholi, grindarholi eða afturskinu (retroperitoneum) eða frír vökvi og/eða frítt loft í kviðarholi samhliða sjúkdómsástandi í ristli sem var orsök rofsins.

Notað var greiningakerfi Alpjóðaheilbrigðisstofnunarinnar (International Classification of Diseases; ICD-10) og gerð víðtæk leit að rofi á ristli auk peirra sjúkdóma par sem rof á ristli er pekktur fylgikvilli (K63.1, K57.2, K57.4, K57.8). Einnig var leitað að greiningarkóðum áverka og óhappa á kviðarhol (S36.5, S36.7, S36.8, S36.6, S36.9, T81.2, Y60.4, Y60.7, Y60.8, Y60.9). Upplýsingum var safnað úr rafræna sjúkraskrárkerfinu og eftir pörfum úr sjúkragögnum á pappírsformi. Upplýsingum um kyn, aldur, greiningarár, innlagnarsjúkrahús, greiningaraðferð, orsök og staðsetningu rofs var safnað og pær skráðar í tölvuforritið Microsoft Excel ${ }^{\circledR}$ (Microsoft, Redmond WA). Reynt var að leggja mat á fylgikvilla sem komu upp við pá bráðameðferð sem var beitt í upphafi sjúkdómsferlisins. Staðsetning rofs var áætluð út frá aðgerðarlýsingu eða lýsingu í myndgreiningarsvari. Skoðað var hversu margir sjúklingar fengu stóma, bæði tímabundið og varanlegt.

Sjúklingar með skyndilega eða bráða kviðverki sem reyndust hafa frítt loft í kviðarholi á kviðarholsyfirliti og/eða tölvusneiðmynd (staðbundið eða dreift), graftarkýli við ristil eða í kviðarholi, grindarholi eða afturskinu á tölvusneiðmynd, frían vökva á tölvusneiðmynd og sjúklingar með lífhimnubólgu sem leiddi til aðgerðar án undangenginnar myndgreiningar voru teknir með í rannsóknina. Undanskildir voru sjúklingar yngri en 18 ára, sjúklingar sem höfðu endaparmsáverka, voru með fistil eða sem fóru í valaðgerð par sem í ljós kom áđur ópekkt rof á ristli. Pá voru sjúklingar sem greindust með rof á ristli við krufningu undanskildir.

Stuðningsmeðferð fól í sér föstu og gjöf sýklalyfja í æð með eða án ísetningar á kera með aðstoð tölvusneiðmyndar eða ómskoðunar. Aðgerð taldist öll inngrip sem framkvæmd voru í svæfingu á skurðstofu. Í peim tilvikum par sem aðgerð var hafin með kviðsjárspeglun en breytt í opna aðgerð og pegar kviðsjárspeglun til greiningar var breytt í skolun á kviðarholi og ísetningu kera, var seinni aðgerðin skráð sem aðalaðgerð.

Sárasýking hjá peim sem fengu stuðningsmeðferð á við um pá sem ekki svöruðu stuðningsmeðferð og fóru síðar í aðgerð. Með endurtengingartíðni eftir Hartmanns-aðgerð var við gagnasöfnun tekið mið af öllum peim sjúklingum sem lifðu lengur en eitt ár og höfðu gengist undir endurtengingu.
Tafla I. Staðsetning rofs í ristli fyrir allan hópinn (n=225), pá sjúklinga sem höfðu sarpabólgu og pá sem ekki voru með sarpabólgu sem ástæðu rofs, $n$ (\%).

\begin{tabular}{lccc} 
& Allir & Sarpabólga & Ekki sarpabólga \\
\hline Botnristill & $14(6,2)$ & $0(0)$ & $14(18,7)$ \\
\hline Hægri hluti ristils & $7(3,1)$ & $0(0)$ & $7(9,3)$ \\
\hline Pverristill & $7(3,1)$ & $0(0)$ & $7(9,3)$ \\
\hline Vinstri hluti ristils & $13(5,8)$ & $2(1,3)$ & $11(14,7)$ \\
\hline Bugaristill & $173(76,9)$ & $146(97,4)$ & $27(36)$ \\
\hline Annað/Ópekkt & $11(4,9)$ & $2(1,3)$ & $9(12)$ \\
\hline Samtals & $225(100)$ & $150(100)$ & $75(100)$ \\
\hline
\end{tabular}

Reiknuð var 30 daga dánartíðni og eins árs dánartíðni en ekki var lagt mat á hvort dánarorsök væri bein afleiðing rofs á ristli eða vegna annarra orsaka.

Sótt var um leyfi fyrir rannsókninni hjá Persónuvernd (2009020159LSL), vísindasiðanefnd (VSN62009020022/03.15), framkvæmdastjórum lækninga á Landspítala, Sjúkrahúsinu á Akureyri og Heilbrigðisstofnun Vesturlands á Akranesi.

Tölfræði var að mestu lýsandi. Marktæki var reiknað með kíkvaðrati og miðað við $\mathrm{p} \leq 0,05$. Við útreikinga á aldursstöðluðu nýgengi voru notaðar tölur frá Alpjóðaheilbrigðisstofnuninni fyrir Evrópu.

\section{Niðurstödur}

Upphafleg leit skilaði 767 sjúklingum en af peim uppfylltu 225 sjúklingar skilyrði rannsóknarinnar. Konur voru 131 (58\%) og karlar 94 (42\%). Miðgildi aldurs var 70 ár (bil: 30-95 ár). Konur voru marktækt eldri en karlar en pær voru 73 ára en karlar 63 ára $(\mathrm{p}<0,01)$, miðgildi. Aldursstaðlað nýgengi var 7,7 tilfelli á hverja 100.000 íbúa á ári á rannsóknartímanum; 6,7 tilfelli á fyrri 5 árunum (1998-2002) en 8,7 tilfelli á seinni 5 árunum (2003-2007) $(\mathrm{p}<0,05)$. Meirihluti sjúklinga var meðhöndlaður á Landspítala, eða 183 (81\%), 33 (15\%) á Sjúkrahúsinu á Akureyri en 8 sjúklingar (4\%) voru meðhöndlaðir á Heilbrigðisstofnun Vesturlands á Akranesi.

\section{Orsakir og staðsetning}

Algengasta orsök rofs á ristli var sarpabólga, eða hjá 150 sjúklingum (67\%). Aðrar orsakir voru meðal annars áverki við ristilspeglun (12\%), áverki í skurðaðgerð (5\%) og krabbamein (1\%) (mynd 1).

pegar allar orsakir rofs á ristli voru skoðaðar var algengasta staðsetning á bugaristli (colon sigmoideum) ( $\mathrm{n}=173,76,9 \%)$. Pegar rof vegna sarpabólgu var undanskilið var bugaristill enn algengasta staðsetningin ( $\mathrm{n}=27,36 \%$ ) (tafla I).

\section{Meðferð}

Fyrsta meðferð var skurðaðgerð, stuðningsmeðferð eða líknarmeðferð. Fyrsta meðferð hjá 134 (60\%) sjúklingum var skurðaðgerð en 88 sjúklingar (39\%) fengu upphaflega stuðningsmeðferð. Í premur tilfellum (1\%) var líknarmeðferð ákveðin (mynd 2).

Hjá peim 134 sjúklingum sem fóru í bráđa aðgerð við greiningu var algengasta aðgerðin Hartmanns-aðgerð (n=63, 47\%). Næst al- 


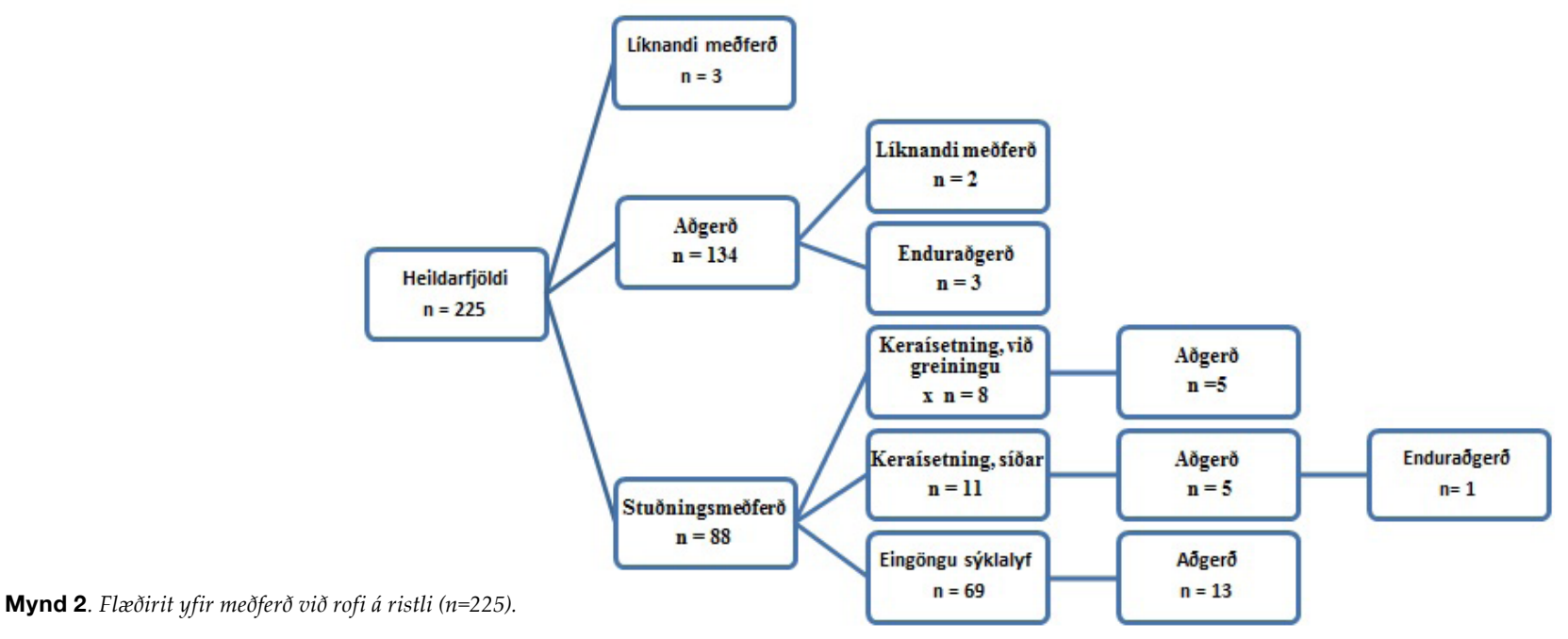

gengasta aðgerðin var brottnám á bugaristli með samtengingu milli ristils og endaparms $(n=30,18 \%)$. Hjá tveimur sjúklingum af 5 sem fóru í greiningaraðgerð með kviðsjá var framkvæmd skolun á kviðarholi. Enginn af pessum 5 sjúklingum fór síðar í bráða- eða valaðgerð (tafla II).

Prír af peim 134 sjúklingum sem fóru í aðgerð purftu á enduraðgerð halda í legunni en allir fóru peir upphaflega í Hartmannsaðgerð. Tveir peirra fóru í heildarbrottnám á ristli (total colectomy) og endagarnarstóma (end ileostomy) vegna versnunar á klínísku ástandi. priðji sjúklingurinn fékk drep í stóma sem parfnaðist lagfæringar. Enn aðrir tveir sjúklingar af 134 sem fóru í aðgerð svöruðu ekki meðferð og í kjölfarið var virkri meðferð hætt (mynd 2).

Átta af 88 sjúklingum (9\%) í stuðningsmeðferðarhópnum fengu kera í kjölfar greiningar, en 11 sjúklingar (12,5\%) fengu kera síðar í legunni par sem peir svöruðu ekki upphafsmeðferð. Flestir sjúklingarnir ( $\mathrm{n}=69,74,5 \%)$ voru upphaflega meðhöndlaðir með sýklalyfjum án ísetningar kera. Tuttugu og prír sjúklingar (26\%) úr stuðningsmeðferðarhópnum purftu síðar að fara í bráðaaðgerð í legunni par sem peir svöruðu ekki meðferð. Tíu af pessum 23 sjúklingum höfðu áður fengið kera (við greiningu, $n=5$; síðar, $n=5$ ) en 13 höfðu eingöngu verið meðhöndlaðir með sýklalyfjum. Раð voru pví samtals 56 sjúklingar sem svöruðu einvörðungu sýklalyfjameðferð. Einn af peim 23 sjúklingum sem upphaflega voru meðhöndlaðir með stuðningsmeðferð og sem síðar fóru í bráðaaðgerð purfti að fara í tvær enduraðgerðir. Upphaflega var framkvæmd opin aðgerð par sem lagður var keri og síðar kviðsjáraðgerð par sem lagt var út stóma (mynd 2).

Valaðgerð var framkvæmd síðar á 10 sjúklingum úr stuðningsmeðferðarhópnum vegna sögu um endurtekna sarpabólgu. Níu

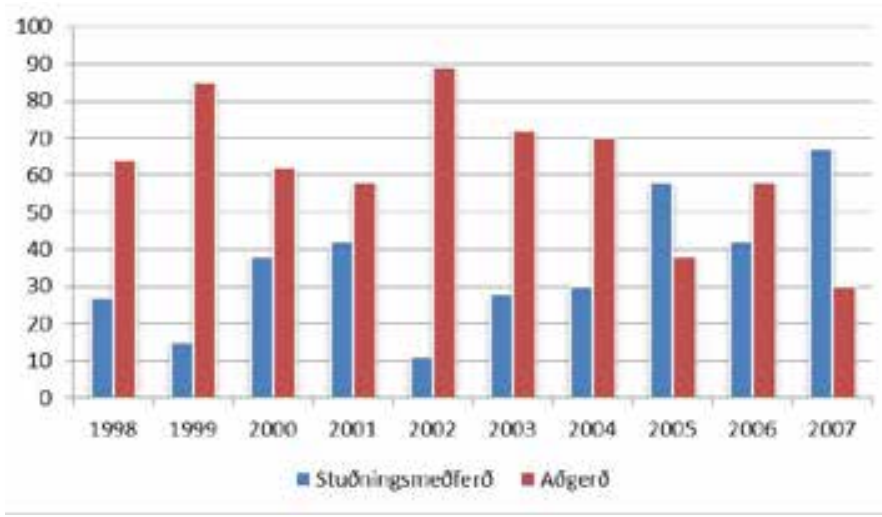

Mynd 3. Fyrsta meðferð við rofi á ristli. Rauðu súlurnar sýna hlutfall aðgerðar og bláu súlurnar hlutfall stuðningsmeðferðar af pessum tveimur meðferðarúrræðum á árunum 1998 til 2007.
Tafla II. Skurðaðgerðir sem framkvæmdar voru sem upphafsmeðferð við rofi á ristli $(n=134)$ eða siðar sem meðferð i kjölfar stuðningsmeðferðar ( $n=33)$. Gefinn er upp fjöldi aðgerða og hlutfall peirra (\%) af heildaraðgerðafjölda í hverjum dálki.

\begin{tabular}{lccc}
\hline & $\begin{array}{c}\text { Aðgerð, fyrsta } \\
\text { meðferð }\end{array}$ & $\begin{array}{c}\text { Aðgerð, seinni } \\
\text { meðferð }\end{array}$ & $\begin{array}{c}\text { Allar } \\
\text { aðgerðir }\end{array}$ \\
\hline Hartmanns-aðgerð & $63(47)$ & $7(21,2)$ & $70(42)$ \\
\hline Brottnám á bugaristli & $15(11,2)$ & $15(45,4)$ & $30(18)$ \\
\hline Rof saumað & $23(17,2)$ & $1(3)$ & $24(14)$ \\
\hline Vinstra helftarristilnám & $6(4,5)$ & $5(15,2)$ & $11(7)$ \\
\hline Brottnám ristils & $8(6)$ & $0(0)$ & $8(5)$ \\
\hline $\begin{array}{l}\text { Kviðsjárspeglun til } \\
\text { greiningar }\end{array}$ & $5(3,7)$ & $0(0)$ & $5(3)$ \\
\hline Hægra helftarristilnám & $4(3)$ & $1(3)$ & $5(3)$ \\
\hline Opin hreinsun & $3(2,2)$ & $2(6,1)$ & $5(3)$ \\
\hline Annað & $7(5,2)$ & $2(6,1)$ & $9(5)$ \\
\hline
\end{tabular}

peirra fóru í brottnám á bugaristli og einn í vinstra helftarristilnám (left hemicolectomy). Í öllum aðgerðum var gerð samtenging á milli ristils og endaparms. Af peim sem upphaflega fengu stuðningsmeðferð fóru pví 33 (38\%) sjúklingar síðar í aðgerð (bráðaaðgerð, $\mathrm{n}=23$; valaðgerð, $\mathrm{n=10)}$. Allir pessir sjúklingar höfðu sarpabólgu.

Stuðningsmeðferð varð algengari eftir pví sem á rannsóknartímann leið en á sama tíma dró úr tíðni skurðaðgerða (mynd 3). Hlutfall sjúklinga sem fóru í aðgerð strax við greiningu lækkaði úr 71\% á tímabilinu 1998-2002 í 54\% á tímabilinu 2003-2007 ( $p<0,005)$. Hlutfall peirra sem voru meðhöndlaðir með stuðningsmeðferð við greiningu jókst úr 27\% á tímabilinu 1998-2002 í 45\% á tímabilinu 2003-2007 $(\mathrm{p}<0,05)$.

\section{Stóma}

Níutíu og sex sjúklingar (61\%) af peim 157 (aðgerðarhópur, n=134; stuðningsmeðferðarhópur, $\mathrm{n}=23$ ) sem fóru í bráðaaðgerð fengu stóma. Sjötíu (73\%) af pessum 96 fóru í Hartmanns-aðgerð (aðgerðarhópur, $n=63$; stuðningsmeðferðarhópur, $n=7$ ) og af peim voru 33 (47\%) endurtengdir síðar. Tuttugu sjúklingar (21\%) létust innan eins árs frá pví að Hartmanns-aðgerðin var framkvæmd án pess að endurtenging færi fram. Рað voru pví 17 (34\%) af 50 sjúklingum sem voru með varanlegt stóma pegar gögnum var safnað. Aldur peirra sjúklinga sem fóru í endurtengingu eftir Hartmannsaðgerð var 62 ár (bil: 35-89) en 71 (bil: 56-86) ár hjá peim sem ekki voru endurtengdir. 
Tafla III. Fylgikvillar hjá peim sem fóru í bráđaaðgerð eđa fengu stuðningsmeðferð ( $n=222)$, peim sem fóru í aðgerð $(n=134)$ og peim sem fengu stuðningsmeðferð ( $n=88)$ sem fyrstu meðferð, $n$ (\%). Hver sjúklingur getur hafa fengið fleiri en einn fylgikvilla.

\begin{tabular}{lccc}
\hline & Allir & Aðgerð** & Stuðningsmeðferð** \\
\hline Sárasýking & $22(9,8)$ & $17(12,7)$ & $5(21,7)^{3}$ \\
\hline $\begin{array}{l}\text { Graftarkýli í grindar- og } \\
\text { kviðarholi }\end{array}$ & $20(8,9)$ & $6(4,5)$ & $14(15,9)$ \\
\hline Sýklasótt & $17(8,4)$ & $14(10,4)$ & $3(3,4)$ \\
\hline Fistill & $11(4,9)$ & $3(2,2)$ & $8(9,1)$ \\
\hline Öndunarbilun & $11(4,9)$ & $10(7,5)$ & $1(1,1)$ \\
\hline Sárarof/örkviðslit & $8(3,6)$ & $7(5,2)$ & $1(1,1)^{3}$ \\
\hline Stómadrep & $7(3,1)$ & $7(5,2)$ & $0(0)$ \\
\hline Nýrnabilun & $4(2,2)$ & $2(1,5)$ & $2(2,3)$ \\
\hline Fjölkerfabilun & $5(2,2)$ & $5(3,7)$ & $0(0)$ \\
\hline Gáttaflökt & $4(1,8)$ & $4(3)$ & $0(0)$ \\
\hline Lungnarek & $3(1,3)$ & $3(2,2)$ & $0(0)$ \\
\hline Hjartabilun & $3(1,3)$ & $2(1,5)$ & $1(1,1)$ \\
\hline Annað & $25(11,1)$ & $21(15,7)$ & $4(4,5)$ \\
\hline Hittal her & & & \\
\hline & & & \\
\hline
\end{tabular}

'Hlutfall heildarpýðis.

"Hlutfall peirra sem fengu viðkomandi meðferð.

- Hlutfall peirra sem fóru í bráđaaðgerð pví stuð̋ningsmeðferð brást.

-'Sjúklingar með graftarkýli við greiningu undanskildir.

Tuttugu og sjö sjúklingar sem ekki fóru í Hartmanns-aðgerð fengu lykkju garnastóma (loop ileostomy) $(\mathrm{n}=9)$, endagarnarstóma (end ileostomy) $(\mathrm{n}=8)$, lykkju-bugaristilstóma (loop sigmoidostomy) $(\mathrm{n}=2)$, endaristilstóma (end colostomy) $(\mathrm{n}=5)$ og lykkju-pverristilstóma (loop transversostomy) ( $\mathrm{n}=3)$. Var $13(50 \%)$ peirra sökkt síðar. Sjö (27\%) sjúklingar létust innan eins árs frá upphaflegu aðgerðinni og pað voru pví 6 sjúklingar (32\%) af 19 með varanlegt stóma eftir aðrar aðgerðir en Hartmanns-aðgerð.

Samtals voru pví 23 sjúklingar (33\%) með varanlegt stóma (Hartmanns-aðgerð n=17, stóma eftir aðrar aðgerðir $n=6$ ) af peim 96 sem fengu upphaflega stóma, ef undanskildir eru peir sjúklingar sem létust innan eins árs ( $n=27)$ frá upphaflegu aðgerðinni.

\section{Fylgikvillar}

Af peim 222 sjúklingum sem fóru í aðgerð eða fengu stuðningsmeðferð fengu 101 sjúklingur (46\%) 140 fylgikvilla. Í aðgerðarhópnum fengu 70 (52\%) af 134 sjúklingum 101 fylgikvilla og í stuðningsmeðferðarhópnum fékk 31 sjúklingur (35\%) 39 fylgikvilla $(\mathrm{p}=0,01)$ (tafla III).

Algengustu fylgikvillarnir hjá aðgerðarhópnum í samanburði við stuðningsmeðferðarhópinn voru sárasýking (12,7 á móti 21,7\%), graftarkýli innan kviðarhols (4,5 á móti 15,9\%), sýklasótt (10,4 á móti 3,4\%), fistlamyndun (2,2 á móti 9,1\%) og öndunarbilun (7,5 á móti $1,1 \%)$.

Prjátíu daga dánartíðni fyrir allan sjúklingahópinn var $11 \%$ $(\mathrm{n}=25)$ og eins árs dánartíðni $20 \%(\mathrm{n}=46)$. Prjátíu daga dánartíðni fyrir aðgerðarhópinn var 13\% (n=17) og 6\% (n=5) fyrir stuðningsmeðferðarhópinn $(p<0,01)$. Enginn af peim sem fór í valaðgerð lést innan árs frá aðgerð.

\section{Umræður}

Meðferð rofs á ristli hefur tekið stakkaskiptum á undanförnum árum. Færri sjúklingar fara í meiriháttar skurðaðgerð en notkun stuðningsmeðferðar með sýklalyfjum og kerum hefur aukist. ${ }^{11,12}$ Nýir meðferðarmöguleikar eins og skolun kviðarhols með kviðsjá og viðgerð á rofi með ristilspeglun eiga ef til vill eftir að ýta enn frekar undir pessa próun pó hún sé enn umdeild. ${ }^{14,15,18,19}$ Pessi próun virðist samkvæmt rannsóknum ekki hafa skert gæði meðferðar heldur orðið til pess að færri sjúklingar purfa á stóma að halda. Pannig hafa lífsgæði batnað auk pess sem tíðni fylgikvilla hefur lækkað. ${ }^{11,14,20}$ Niðurstöður okkar sýna sambærilegar tölur yfir fylgikvilla og dánartíðni og sést hafa í erlendum rannsóknum. ${ }^{2,711,16}$

Há tíðni sarpabólgu sem undirliggjandi orsök rofs kemur ekki á óvart og er í takt við pekktar, algengar orsakir rofs á ristli. ${ }^{2}$ Endurtengingartíðni hérlendis er sambærileg og lýst er í erlendum rannsóknum, en algengt hlutfall er á bilinu 45-55\%. ${ }^{8,9}$ Hlutfall peirra sem lifa lengur en eitt ár og fara í endurtengingu eftir Hartmanns-aðgerð er hátt hérlendis, eða 66\%. Ein skýringin á pví gæti verið nákvæmni í eftirfylgd okkar en enginn sjúklingur úr rannsóknarhópnum datt úr eftirliti. Önnur skýring gæti verið gott aðgengi að heilbrigðispjónustu á Íslandi. Samkvæmt erlendum rannsóknum er aldur sá páttur sem ræður hvað mestu um hvort endurtenging eftir Hartmanns-aðgerð eigi sér stað eða ekki en ekki er hægt að fullyrða út frá okkar niðurstöðum hvort sá páttur hafi haft áhrif á pað. ${ }^{21}$

Fjórðungur sjúklinga sem upphaflega fengu stuðningsmeðferð svaraði henni ekki á fullnægjandi hátt og purfti að fara í aðgerð í sömu legu. Við teljum $74 \%$ árangur af stuðningsmeðferð við rofi á ristli í bráđafasa ásættanlegan. Рað er athyglisvert að einungis $44 \%$ sjúklinganna úr stuðningsmeðferðarhópnum sem purfti á aðgerð að halda fengu kera fyrir aðgerð. Par sem rannsóknin var afturskyggn var ekki hægt að leggja mat á ferlið sem leiddi til aðgerðar. Gera má ráð fyrir að klínískt ástand sjúklinganna hafi ekki boðið upp á áframhaldandi stuðningsmeðferð með ísetningu kera eða að ekki hafi verið hægt að koma fyrir kera að mati röntgenlæknis.

Niðurstöður rannsóknarinnar sýna marktæka aukningu á tíðni rofs á ristli á rannsóknartímabilinu. ঙó að ekki hafi verið skoðað hvort pessi aukning sé af völdum ákveðinnar orsakar, svo sem rofs í kjölfar sarpabólgu, má draga pá ályktun par sem sarpabólga er algengasta ástæða rofs á ristli. Aðrir hafa sýnt fram á aukna tíðni ristilbólgu og aukna tíðni rofs á ristli vegna sarpabólgu. Hlutfall peirra sem fengu sarpabólgu jókst pó ekki. Pví má draga pá ályktun að pó fleiri séu að fá rof á ristli sé pað fyrst og fremst vegna pess að fleiri fá sarpabólgu nú en áður. Pó sýnt hafi verið fram á að tíðni rofs á ristli af völdum sarpabólgu hafi ekki aukist (1,5\%), hefur tíðni sarpabólgu aukist sem skýrir fleiri rof á ristli nú en áđur. ${ }^{22}$ Par sem sarpabólga var algengasta ástæða ristilrofs í rannsóknarhópnum má leiða líkur að pví að aukin tíðni sarpabólgu skýri aukna tíðni rofs á ristli.

Veikleiki pessarar rannsóknar er að hún er afturskyggn. Fyrsta leit var gerð með fjölda greiningarkóða sem gaf okkur mörg hundruð sjúklinga og reyndust margir peirra hafa ranga greiningarkóða. Pessi ónákvæma skráning er pví miður pekkt vandamál. Annar veikleiki er hversu margbreytilegur rannsóknarhópurinn er og hversu misjafnt ástand sjúklinga var við greiningu. Gera má 
ráð fyrir að sjúklingar sem fóru beint í aðgerð hafi verið veikari en peir sem fengu stuðningsmeðferð. Par sem ASA-skor var illa skráð og sjúklingar ekki flokkaðir í undirflokka eftir alvarleika einkenna, var ekki hægt að styðja pað með gögnum. аð verður pví að hafa í huga við allan samanburð að hóparnir geta verið mjög ólíkir.

Margbreytileiki hópsins er einnig helsti styrkur pessarar rannsóknar. Rannsóknin nær til allra sjúklinga með rof á ristli á Íslandi á rannsóknartímabilinu, par sem gera má ráð fyrir að önnur sjúkrahús en pau sem tóku pátt meðhöndli ekki sjúklinga sem uppfylla inntökuskilyrði. Rannsóknin er með bæði langt rannsóknartímabil og mikinn fjölda sjúklinga og gefur pví góða mynd af pessu alvarlega vandamáli sem rof á ristli er hér á landi, orsökum pess og árangri meðferðar.

\section{Pakkir}

Höfundar vilja pakka riturum peirra sjúkrahúsa sem pátt tóku fyrir hjálp við að afla gagna. Sérstakar pakkir fær Gunnhildur Jóhannsdóttir, Landspítala, og Hjörtur Brynjólfsson, læknir á Sjúkrahúsinu á Akureyri. Pá fá Martin Ingi Sigurðsson og Sigrún Helga Lund pakkir fyrir veitta tölfræðiaðstoð.

\section{Heimildir}

1. Sheth AA, Longo W, Floch MH. Diverticular Disease and Diverticulitis. Am J Gastroenterol 2008;103: 1550-6.

2. Biondo S, Parés D, Ragué JM, Oca J, Toral D, Borobia FG, et al. Emergency operation for Nondiverticular perforation of the left colon. Am J Surg 2002; 183: 256-60.

3. Iqbal CW, Cullinane DC, Schiller HJ, Sawyer MD, Zietlow SP, Farley DR. Surgical management and outcomes of 165 colonoscopic perforations from a single institution. Arch Surg 2008; 143: 701-7.

4. Lüning TH, Keemers-Gels ME, Barendregt WB, Tan AC, Rosman C. Colonoscopic perforations: a review of 30,366 patients. Surg Endosc 2007; 21: 994-7.

5. Panteris V, Haringsma J, Kuipers EJ. Colonoscopy perforation rate, mechanisms and outcome: from diagnostic to therapeutic colonoscopy. Endoscopy 2009; 41: 941-51.

6. Sosna J, Blachar A, Amitai M, Barmeir E, Peled $\mathrm{N}$, Goldberg SN, et al. Colonic perforation at CT colonography: assessment of risk in a multicenter large cohort. Radiology 2006; 239: 457-63.

7. Tulchinsky $\mathrm{H}$, Madhala-Givon $\mathrm{O}$, Wasserberg $\mathrm{N}$, Lelcuk $\mathrm{S}$, Niv Y. Incidence and management of colonoscopic perforations: 8 years' experience. World J Gastroenterol 2006; 12: 4211-3.

8. Vermeulen J, Coene PP, Van Hout NM, van der Harst E, Gosselink MP, Mannaerts GH, et al. Restoration of bowe continuity after surgery for acute perforated diverticulitis: should Hartmann's procedure be considered a one-stage procedure? Colorectal Dis 2009; $11: 619-24$
9. Toro A, Mannino M, Reale G, Capello G, Di Carlo I. Primary anastomosis vs. Hartmann procedure in acute complicated diverticulitis. Evolution over the last twenty years. Chirurgia (Bucur) 2012; 107: 598-604.

10. Oomen JL, Cuesta MA, Engel AF. Reversal of Hartmann's procedure after surgery for complications of diverticula disease of the sigmoid colon is safe and possible in mos patients. Dig Surg 2005; 22: 419-25.

11. Chandra V, Nelson H, Larson DR, Harrington JR. Impact of primary resection on the outcome of patients with perforated diverticulitis. Arch Surg 2004; 139: 1221-4.

12. Durmishi Y, Gervaz P, Brandt D, Bucher P, Platon A, More $\mathrm{P}$, et al. Results from percutaneous drainage of Hinchey stage II diverticulitis guided by computer tomography can. Surg Endosc 2006; 20: 1129-33.

13. Fingerhut A, Veyrie N. Complicated diverticular disease: the changing paradigm for treatment. Rev Col Bras Cir 2012; 39: 322-7.

14. Karoui M, Champault A, Pautrat K, Valleur $\mathrm{P}$, Cherqui $\mathrm{D}_{\text {, }}$ Champault G. Laparascopic peritoneal lavage or primary anastamosis with defunctioning stoma for hinchey 3 complicated diverticulitis: results of a comparative study Dis Colon Rectum 2009; 52: 609-15.

15. Toorenvliet BR, Swank $\mathrm{H}$, Schoones JW, Haming JF, Bemelman WA. Laparoscopic peritoneal lavage for perforated colonic diverticulitis: systematic review. Colorectal Dis 2010; 12: 862-7.
16. Morris CR, Harvey IM, Stebbing WS, Hart AR. Incidence of perforated diverticulitis and risk factors for death in a UK population. Br J Surg 2008; 95: 876-81

17. Constantinides VA, Tekkis PP, Athanasiou T, Aziz O, Purkayastha S, Remzi FH, et al. Primary resection with anastamosis vs. Hartmann's procedure in nonelective surgery for acute colonic diverticulitis: a systematic review. Dis Colon Rectum 2006; 49: 966-81.

18. Trecca A, Gaj F, Gagliardi G. Our experience with endoscopic repair of large colonoscopic perforations and review of the literature. Tech Coloproctol 2008; 12: 315-21.

19. Feingold D et al. Practice parameters for the treatment of sigmoid diverticulitis. Dis Colon Rectum 2014; 57: 284-94.

20. Vermeulen J, Gosselink MP, Busschback JJ, Lange JF. Avoiding or reversing Hartmann's procedure provides improved quality of life after perforated diverticulitis. J Gastrointest Surg 2010; 14: 651-7.

21. Hodgson R, An V, Stupart DA, Guest GD, Watters DA. Who gets Hartmann's reversed in a regional centre? Surgeon 2016; 14: 184-9.

22. Ricciardi R, Baxter NN, Read TE, Marcello PW, Hall J, Roberts PL. Is the decline in the surgical treatment for diverticulitis associated with an increase in complicated diverticultis? Dis Colon Rectum 2009; 52: 1558-63.

\section{ENGLISH SUMMARY}

\section{Incidence, cause and treatment of colonic perforations in Iceland 1998-2007: A nationwide study}

Kristín Jónsdóttir ${ }^{1}$, Elsa B. Valsdóttir ${ }^{2}$, Shreekrishna Datye ${ }^{3}$, Fritz Berndsen ${ }^{4}$, Páll Helgi Möller ${ }^{1,2}$

Introduction: Colon perforation is a serious illness with mortality reported from $0-39 \%$. Surgery used to be the gold standard but treatment has changed as studies have indicated comparable results with less invasive treatment. The aim of this study was to evaluate the incidence of acute colon perforations in Iceland, causes and treatment.

Material and methods: A retrospective, nationwide, multicenter analysis was performed based on ICD-10 codes from databases of the main hospitals in Iceland. Age, gender, year of perforation, cause, means of diagnosis, treatment and outcome were registered. Patients under 18 years and post mortem diagnosis were excluded.

Results: 225 patients met criteria, 131 women (58\%) and 94 men (42\%), median age 70 years (range 30-95). The most common causes were diverticulitis (67\%), colonoscopy (12\%) and complications during operations $(5 \%)$. During the first five study years, $27 \%$ received conservative treatment while $71 \%$ underwent surgery. By the end of the study era this ratio was $45 \%$ and $54 \%$ respectively. The rate of permanent stoma was $10 \%$.

Conclusions: Diverticulitis was the most common cause of colon perforation in Iceland during the study period. Many patients still undergo surgery but there has been a dramatic change toward more conservative treatment. The rate of stoma closure is comparable to studies elsewhere. 